\title{
Evaluation of Effect of Labour Strikes on Patient Satisfaction in Secondary Health Institutions in Cross River State, Nigeria
}

Article by Samson Olusegun Aturaka ${ }^{1}$, Ademola Amosu ${ }^{2}$, Felix Sanni ${ }^{3}$, Musa Orenyi ${ }^{4}$, Margaret Dakwat ${ }^{5}$, Abiodun Olaiya Paul ${ }^{6}$, Opeyemi Joseph ${ }^{7}$

${ }^{1}$ Department of Public Health, Texila American University, Guyana, South America

${ }^{2}$ Department of Public Health, School of Allied Public and Allied Health, Babcock University, Nigeria

${ }^{3}$ Department of Chemistry, Federal University of Agriculture, Nigeria

${ }^{4}$ Department of Supply Chain Management and Operations, Nigeria

${ }^{5}$ Department of Health system strengthening and Laboratory services, Nigeria

${ }^{6}$ Department of Public Health, Texila American University, Guyana, South America

${ }^{7}$ Department of Health System Strengthening and Laboratory Sevices, Nigeria E-mail: segunhydd@yahoo.com ${ }^{1}$

\begin{abstract}
The objective of the study is to evaluate the effect of labour strikes patient satisfaction in secondary Health Institutions in Cross River State, Nigeria. The study is cross-sectional descriptive study of 508 respondents form outpatient department, laboratory department, pharmacy department, Ante-Natal and Post-Natal clinic and ART clinic at the 7 secondary health institutions in CRS spread across 3 senatorial districts in the state between January and February 2018 using semi structured; selfadministered, closed-and open-ended questionnaires that were divided into different sections each. Raw data were entered EpiData ${ }^{\mathrm{TM}}$ and exported for analysis using the SPSS software version 20. The data were cleaned and validated for use. Frequency tables were produced and associations between categorical variables were determined using chi squared test at a significance level of $P<0.05$.

Meanwhile, the negative effects of strikes are generally highly felt among all patients with no statistical significant difference whether employed, unemployed or retired $(P>0.05)$. One of the effects of health workers' strike is that strikes increase death rates and the result showed that regardless of patient's education level, patients are fully aware that one of the effects of frequent strikes is increase in death rate $(P>0.05)$. The result indicates that there is statistical significant difference in respondents' responses between those without formal education, non-graduates and graduates. i.e. the higher the level of education, the higher the awareness that labour strikes affect the duty of health workers and have effect on patient's attendance, poor healthcare performance and cause patients' dissatisfaction $(P<0.05)$.
\end{abstract}

Keywords: Labour Strikes, Patient Satisfaction, Access to Service Delivery, Quality of Care and Secondary Health Institutions.

\section{Introduction}

Nigeria masses have suffered from frequent healthcare workers' strikes from 2012 to date from witnessing several health worker's strikes involving all health professionals. Frequent healthcare workers' strikes result from the closure of public healthcare institutions preventing Nigerians' access to quality health services (Olerebe, 2016).

There are so many reasons health professionals go on strike. The main underlying causes of industrial action Nigeria include career stagnation, perceived discriminatory policies and demoralization from working in systems with poor infrastructure, manpower shortages and poor personal remuneration (Ogunbanjo, 2009). However, in recent times, there has been a divided opinion on true underlying factors responsible for the causes of industrial action (Botero, 2014).

The patient's/client's satisfaction in health institution is mainly identified by healthcare service delivery and quality of care. In health institution, satisfaction is not referred to as a specific product or service; it is composed by a combination of various features. Mostly in health institution, in healthcare 
service delivery especially have regular contact with the patients. Therefore, evaluation and assessment of patients' satisfaction is the paramount objective of healthcare institution (Hill \& Alexander 2006). Meanwhile, Patients' satisfaction has been recognized as a crucial parameter for measuring the quality of healthcare services (Lee, 2015).

The formation process of patients' satisfaction starts with his/her goal setting in terms of service delivery and quality of care. As a rule, this goal is to meet varying patients' needs. After the problem appearance the client starts to check the services available and compares analogues to choose the best one (Kotler et al. 2010).

\section{Materials and methods}

Using the sample size calculation formula for population less than ten thousand, (Olawuyi, 1996) sample size of 508 was calculated. Multistage sampling methods were employed from state ministry of health totaling 12 General hospitals. In stage one, 2 out of the 3 senatorial districts were selected by simple random sampling employing simple ballot in the two selected geopolitical zones. In stage two, 7 out of 9 secondary health facilities were selected from the 2 senatorial districts (Southern and Northern senatorial districts) by simple random sampling. In Stage three, questionnaires were distributed systematically to patients attending the following service delivery points: outpatient department, laboratory department, pharmacy department and ART clinic based on their client load. The patients were informed about the study. Those who agreed to participate were enlisted into the study by signing the consent form. Data collected were cleaned and validated for use. Simple frequency tables were produced and associations between categorical variables were determined using Chi square test at a significance level of $\mathrm{P}<0.05$. Age, Gender, educational qualification, occupation and attendance at the facility were re-coded for the Chi-square analysis. Recoding of variables saw all participants grouped into male and female, graduates and non-graduates, married and single (with widows classified as singles) and attendance at the facility grouped into $<1$ year, $1-5$ years, $6-10$ years, $11-15$ years and $>$ 15 years.

\section{Result and discussion}

Table 1 Demographics

There were $265(52.2 \%)$ males and $243(47.8 \%)$ females with male: female ratio of 1.1:1. The most frequent age group was 25 - 34 with $198(39.0 \%)$ respondents followed by $125(24.6 \%)$ seen for age range $35-44$. There were $92(18.1 \%)$ participants in $18-24$ age group, $75(14.8 \%)$ for $45-54$ while the least value of $18(3.5 \%)$ was seen for 55 years and above. Majority of respondents $(466 ; 87.8 \%)$ were Christians, 49 (9.6\%) Muslims and 13 (2.3\%) were traditional religion worshippers. Also, 83 (16.3\%) of the respondents did not have formal education, 220 (43.3\%) were non-graduates while 205 (40.4\%) were University/college graduates. Most of the respondents, 199 (39.2\%) were self-employed followed by $153(30.1 \%)$ who were gainfully employed while $142(28.0 \%)$ and 14 (2.7\%) were unemployed and retired respectively. The age range of repondents was $25-45$ years (Table 1 ).

Table 1. Socio-demographic characteristics of study participants

\begin{tabular}{llll}
\hline SN & & Number & Perce \\
\hline Gender of respondents & & & \\
1 & Male & 265 & 52.2 \\
2 & Female & 243 & 47.8 \\
Marital status & & & \\
1 & Single & 248 & 48.8 \\
2 & Married & 260 & 51.2
\end{tabular}


Age group

1

2

3

4

\section{Religion}

1

2

3

Level of education

\section{1}

2

3

Employment status

1

2

3

4

Level of education

$$
18-24
$$

$25-34$

198

125

$35-44$

$45-54$

75

18

$55+$

\author{
Christianity
}

Islam

Traditional

13
18.1

39.0

24.6

14.8

3.5

\begin{tabular}{llll} 
& $\begin{array}{l}\text { No formal } \\
\text { education } \\
\text { Non- } \\
\text { graduate }\end{array}$ & 220 & 16.3 \\
Graduate & 205 & 43.3 \\
\hline Employment status & & & 40.4 \\
& $\begin{array}{l}\text { Unemployed } \\
\text { Employed }\end{array}$ & 142 & 28.0 \\
& $\begin{array}{l}\text { Self } \\
\text { employed }\end{array}$ & 199 & 30.1 \\
Retired & 14 & 2.7 \\
\hline
\end{tabular}

More than half of the respondents were out patients in their respective healthcare institutions, 345 $(67.9 \%)$ while $163(32.1 \%)$ were new patients at the time of interview. Majority of the respondents have been using the health their respective health facilities for the period of $1-5$ years $(202 ; 39.8 \%)$, approximately $25 \%$ (131) have been attending for less than a year, $25.4 \%$ (129) for $6-10$ years, $7.9 \%$ (40) for $11-15$ years while just 1.2\% (6) have been using the hospital for over 15 years (Figure 3). 
DOI: $10.21522 /$ TIJCR.2014.05.01.Art005

ISSN: $2520-3096$

Table 2. Hospital attendance history of respondents

\begin{tabular}{llll}
\hline SN & Number & Percent \\
\hline Patient status & & 162 & 32.1 \\
1 & New patient & 345 & 67.9 \\
2 & Returning patient & & \\
Number of years & & 131 & 25.8 \\
in attendance & $<1 \mathrm{yr}$ & 202 & 39.8 \\
1 & $1-5 \mathrm{yrs}$ & 129 & 25.4 \\
2 & $6-10 \mathrm{yrs}$ & 40 & 7.9 \\
4 & $11-15 \mathrm{yrs}$ & 6 & 1.2 \\
5 & $>15 \mathrm{yrs}$ & & \\
\hline
\end{tabular}

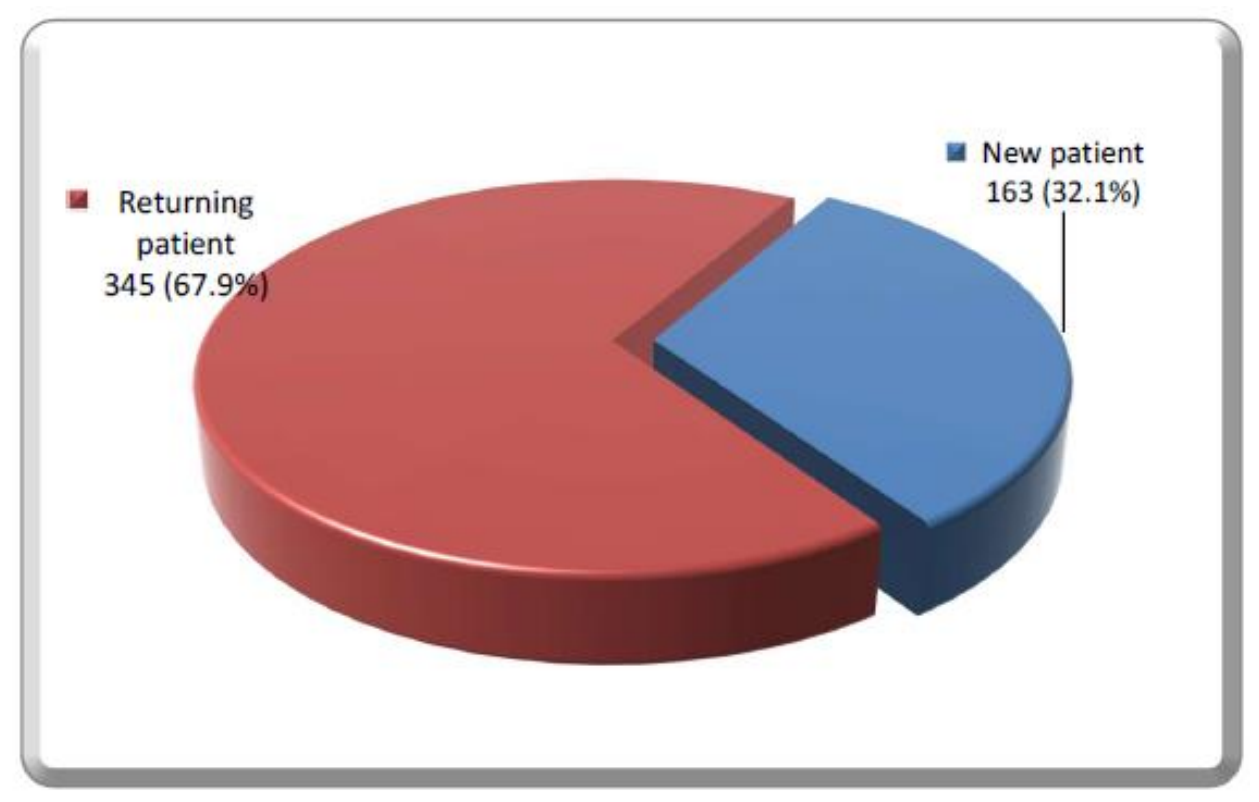

Figure 3. Patient's attendance status

More than half of the respondents were returning patients in their respective healthcare institutions, $345(67.9 \%)$ while $163(32.1 \%)$ were new patients at the time of interview. 


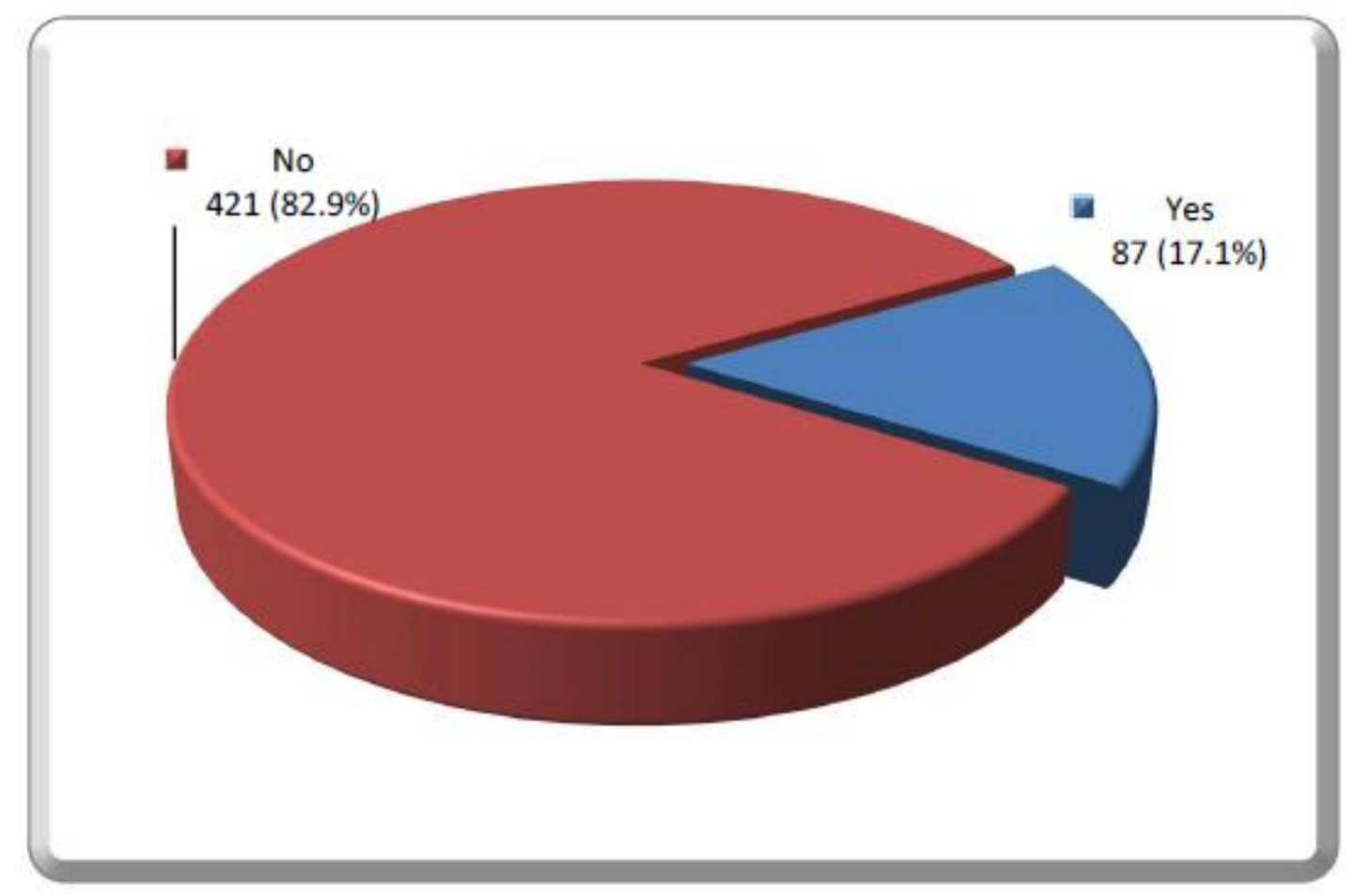

Figure 4. Is this your first time in this hospital?

$87(17.1 \%)$ were in the hospital for the first time during while $421(82.9 \%)$ have been visited the hospital more than once before the day of interview.

\section{Patients' satisfaction with health service during strikes}

This section is to determine the level of patients'satisfaction with health services during labour strikes. The question to ask here is "Can patients' satisfaction be achieved when there are labour strikes? Majority of the respondents $(447 ; 88 \%)$ were not satisfied with health care service during strikes, $92.1 \%$ were unhappy. Over seventy five percent $(75.6 \%)$ go to private hospital during strikes while approximately ninety percent $(89.8 \%)$ were not happy coming to government hospitals during strikes. Majority of respondents stated that strike is unnecessary in the hospitals (76.8\%), 48.8\% believed that strikes are too frequent in health institutions and $71.5 \%$ were unsatisfied because strikes contribute to increase in hospital bills (Table 8).

Table 3. Patients' satisfaction with health service during strikes

\begin{tabular}{|c|c|c|c|}
\hline & Agree & Disagree & Not Sure \\
\hline $\begin{array}{l}\text { Labour strike cause patient's } \\
\text { dissatisfaction }\end{array}$ & $447(88.0 \%)$ & $14(2.8 \%)$ & $47(9.3 \%)$ \\
\hline \multirow[t]{2}{*}{$\begin{array}{l}\text { Patients are not happy during } \\
\text { strike }\end{array}$} & $468(92.1 \%)$ & $13(2.6 \%)$ & $27(5.3 \%)$ \\
\hline & Yes & No & Can't Say \\
\hline $\begin{array}{l}\text { Will you be happy to come to } \\
\text { this health facility during } \\
\text { strikes? }\end{array}$ & $52(10.2 \%)$ & $456(89.8 \%)$ & - \\
\hline $\begin{array}{l}\text { Do you go to private hospital } \\
\text { during strikes? }\end{array}$ & $384(75.6 \%)$ & $124(24.4 \%)$ & - \\
\hline $\begin{array}{l}\text { Is the strike in our hospital too } \\
\text { frequent? }\end{array}$ & $248(48.8 \%)$ & $189(37.2 \%$ & $71(14.0 \%)$ \\
\hline
\end{tabular}




\begin{tabular}{llll}
\hline $\begin{array}{l}\text { Is the strike in the hospital } \\
\text { necessary? }\end{array}$ & $70(13.8 \%)$ & $390(76.8 \%)$ & $48(9.4 \%)$ \\
$\begin{array}{l}\text { Does strike contribute to } \\
\text { increase in hospital bills? }\end{array}$ & $363(71.5 \%)$ & $115(22.6 \%)$ & $30(5.9 \%)$
\end{tabular}

\section{Comparison of the levels of patient's dissatisfaction across gender, education and employment status}

The level of patient's dissatisfaction with health care services during strike is generally high (above $70 \%$ ) across respondent's gender, education and employment status as shown in table 9. Approximately $90 \%$ of female and $87 \%$ of male patients are not satisfied with cares receive during strikes. Across the level of education, the level of dissatisfaction is significantly higher $(92.7 \%)$ than $88.2 \%$ dissatisfaction level found for non-graduates and $75.9 \%$ recorded for those without formal education $(\mathrm{P}<0.05)$. the level of dissatisfation of patients during strike does not depend on employment status as dissatisfaction is very high across all status. Approximatley ninety three percent (92.9\%) dissatisfaction level was discovered among retirees followed by $89.5 \%$ among the employed, $88.4 \%$ among self-employed and the least value of $85.2 \%$ among the umemployed ( $p>0.05$ ) (Table 9).

Table 4. Comparison of the levels of patient's dissatisfaction across gender, education and employment status

\begin{tabular}{|c|c|c|c|}
\hline & & Number & Percent \\
\hline & \multicolumn{3}{|l|}{ Gender of respondents } \\
\hline & Male & 231 & 87.2 \\
\hline & Female & 216 & 88.9 \\
\hline \multicolumn{4}{|l|}{$X^{2} 0.594, P$ value 0.743} \\
\hline & \multicolumn{3}{|l|}{ Level of education of respondents } \\
\hline & No formal education & 63 & 75.9 \\
\hline & Non-graduate & 194 & 88.2 \\
\hline & Graduate & 190 & 92.7 \\
\hline \multicolumn{4}{|l|}{$X^{2} 35.617$, $P$ value 0.000} \\
\hline & \multicolumn{3}{|l|}{ Employment status of respondents } \\
\hline & Unemployed & 121 & 85.2 \\
\hline & Employed & 137 & 89.5 \\
\hline & Self-employed & 176 & 88.4 \\
\hline & Retired & 13 & 92.9 \\
\hline $\mathrm{X}^{2} 3.489, \mathrm{P}$ value 0.745 & & & \\
\hline
\end{tabular}

\section{Discussion}

In the last five years, the Nigerian health system has experienced more than eight different strikes involving doctors, nurses and allied healthcare workers (Olatunji S, 2013; Hassan J., 2016). In fact, there has been an increase in the number of healthcare worker strikes across the country which are national, within the region or state based (Ogunbanjo, 2009; Olatunji, 2015 and Ibe, 2015) However, the felt implications of strikes are also supported by other studies (The Daily Newspaper, 2005).

Majority of the respondents (88\%) were not satisfied with health care service during strikes, $92.1 \%$ were unhappy. Over seventy five percent go to private hospital during strikes while approximately ninety percent were not happy coming to government hospitals during strikes. Majority of respondents stated that strike is unnecessary in the hospitals $(76.8 \%), 48.8 \%$ believed that strikes are too frequent in health institutions and $71.5 \%$ were unsatisfied because strikes contribute to increase in hospital bills. Approximately $90 \%$ of female and $87 \%$ of male patients expressed dissatisfaction with cares receive 
during strikes. Across the level of education, the level of dissatisfaction is significantly higher $(92.7 \%)$ than $88.2 \%$ dissatisfaction level found for non-graduates and $75.9 \%$ recorded for those without formal education. Approximatley ninety three percent dissatisfaction level was discovered among retirees followed by $89.5 \%$ among the employed, $88.4 \%$ among self-employed and the least value of $85.2 \%$ among the umemployed.

Patient satisfaction is an indicator for performance management, it is a very important tool in processing monitoring and improving quality of healthcare services. Assesses what patient think about the care and treatment they have received present one approach to improve the quality of care (Donabedian, 1988). The findings in this study supported the earlier studies in the sense that $86.9 \%$ of respondents agreed that labour strikes causes poor healthcare quality, increase cost; it leads to loss of lives, loss of time, and loss of public confidence, low staff morale and results in wastage of our limited resources while $88.0 \%$ of respondents also agreed that labour strikes affect the duty of health workers and have effect on patient's attendance, poor performance of healthcare and invariably lead to patients dissatisfaction. This shows that effects/impacts of labour strikes are favourably skewed towards healthcare workers since government will still pay for the number of days the workers remain on strike. The participants thus agreed from the study that labour strikes have negative effect generally on patients and their family. Poor healthcare quality is costly; it leads to loss of lives, loss of time, and loss of public confidence, low staff morale and results in wastage of our limited resources (Offei, 2012).

\section{Recommendations}

To avoid frequent strikes in health facilities, the most frequent recommendation cited by respondents was that government should take steps to resolve crisis and negotiate with the health workers union on time (97.8\%). Another major recommendation is that government should take steps to see that basic facilities are in place and ensure that emergency teams are working (96.7\%). Other recommendations include "health workers should work together in harmony and learn to relate with one another peacefully" (96.1\%), "regular training should be organized for leaders in health institutions" (93.9\%), "it should not be compulsory for health workers to join labour unions" (62.8\%) and "healthcare/hospital workers should be restricted/ban from going on strikes" (60.0\%). In the study of Obinna and his team, it was reported that respondents believe that strengthening of the healthcare system (82.7\%), improving financial and professional motivation of health workers (50.7\%) and involving healthcare workers in decision-making $(43.3 \%)$ were workable solutions to the plethora of strike action in Nigeria (Obinna et al., 2016).

\section{References}

[1]. Botero JC, Djankov S, La Porta R, López de Silanes F, Shleifer A. (2004). The Regulation of Labor. The Quarterly Journal of Economics. 2004; 119(4):1339-82. doi: 10.1162/0033553042476215. http://qje.oxfordjournals.org/content/119/4/1339.full.pdf+html.

[2]. Donabedian, A. (1988). The quality of care: How can it be assessed? Journal of the American Medical Association, 260, 1743-1748.

[3]. Hassan J. 'JOHESU strike: issues, resolution and lessons' Daily Independent (online). Posted in: Features September 23, 2013 @ 12:00 am. 2013;

http://www.dailyindependentnig.com/2013/09/johesu-strike-issues-resolutions-and-lessons/. Accessed 10 Apr 2015.

[4]. Hill, Nigel, Alexander, Jim 2006. The Handbook of Customer Satisfaction and Loyalty

[5]. Measurement. Gower Publishing.

[6]. Ibeh N. 'Nigerian health workers call off strike' Premium Times. 2015; http://www.premiumtimesng.com/news/top-news/176152-nigerian-health-workers-call-off-

strike.html. Accessed 10 Apr 2015.

[7]. Kotler, Philip, Armstrong, Gary 2010. Principles of Marketing. Pearson Education.

[8]. Obinna OO, Ezieme IP, Oladipo O, Akinola EP, Udofia D, Taylor-Robinson SD. Industrial action by healthcare workers in Nigeria in 2013-2015: an inquiry into causes, consequences and control-a cross-sectional descriptive study. Hum Resour Health. 2016; 14(1):46. 
DOI: $10.21522 /$ TIJCR.2014.05.01.Art005

ISSN: 2520-3096

[9]. Offei AK, Bannerman C, Kyeremeh K, (2012). Healthcare quality assurance manual. Ghana Health Service, Accra. 2004 available http://beepdf.com/doc/40767/healthcare_quality_assurance_manual.html, last accessed on 9-8-2012. [10].Ogunbanjo G.A. and Knapp van Bogaert D. (2009), Doctors and strike action: can this be morally justifiable? S AfrFamPract. 2009; 51(4):306-8. doi: 10.1080/20786204.2009.10873869.

[11]. Olatunji S. 'Resident doctors begin warning strike on Wednesday' The Punch Newspaper June 25, 2013 (online). 2013; http://www.punchng.com/news/resident-doctors-begin-warning-strike-onwednesday/. Accessed 10 Apr 2015.

[12].Olawuyi, J. F (1996). Choosing the study subjects and sampling. In biostatistics, a foundation course in health sciences. First edition. Yotson consult publishers Ibadan, 110-118.

[13]. Oleribe OO, Ezieme IP, Oladipo O, Akinola EP, Udofia D, Taylor-Robinson SD. Industrial action by healthcare workers in Nigeria in 2013-2015: an inquiry into causes, consequences and control-a cross-sectional descriptive study. Hum Resour Health. 2016; 14(1):46. doi: 10.1186/s12960-016-01427. [PMC free article][PubMed][Cross Ref].

[14].The Daily Times newspaper (2005). Nurses' shortage hits Malawi. The Daily Times, $9^{\text {th }}$ June 2005. 